\title{
1B: Immunological aspects leading to vaccine against $H$. pylori
}

\section{B:01 ORAL IMMUNIZATION WITH RECOMBINANT UREASE WITHOUT ADJUVANT IN H. PYLORI-INFECTED HUMANS}

C. Kreiss, T. Buclin, M. Cosma, J. Biollaz, I. Corthésy-Theulaz, N. Porta, M. Glauser, M. Appenzeller, J. Pappo, R. Nichols, M. Stolte, T. Monath, A.L. Blum, P. Michetti. University Hospital of Lausanne, Switzerland; University Hospital of Bayreuth, Germany; University Hospital of OraVax, Cambridge, USA

Oral immunization with $H$. pylori urease induces the cure of Helicobacter infection in animal models, when administered with an adjuvant. As a first step to use therapeutic immunization in humans, we studied the safety and the immunogenicity of recombinant, enzymatically inactive urease in H. pylori-infected adults. Methods: 12 healthy adults (21-39 yrs.) with documented asymptomatic $H$. pylori infection, participated in a doubleblind, placebo-controlled phase 1 study and were randomized to receive 60 $\mathrm{mg}$ recombinant urease po or placebo once weekly for 4 weeks. Clinical examination and safety laboratory tests were performed at regular intervals. Gastric biopsies obtained at baseline and one month after the last dose were scored for inflammation, mucosal damage, and $H$. pylori density according to a modified Sydney system and were analysed by immunocytochemistry. Urease-specific antibody-secreting cells (ASC) were measured in peripheral blood by ELISPOT and antibodies to urease were determined in saliva and serum. Results: The administration of urease was well tolerated and no serious adverse events occurred. No clinically relevant abnormalities in blood count or chemistry were observed. All baseline gastroscopies were normal except for antral non-erosive gastritis. At the end of the study, isolated erosions were noted in 2 volunteers having received placebo and in 3 having received urease. No change in the total gastritis score for corpus and antrum was observed. All subjects remained infected throughout the study $\left({ }^{13} \mathrm{C}\right.$-urea breath test, culture, and histology). ASC were found in gastric mucosa of most subjects and there was no evidence that immunization with urease enhanced the local antibody response. No urease-specific ASC were detected in peripheral blood throughout the study. Antibodies to urease were detected in saliva and serum of all subjects. Serum IgG and IgA anti-urease titers remained unchanged in all volunteers. One of six subjects having received the test product developed a borderline increase (3.4 fold) in salivary anti-urease IgA. No change in salivary anti-urease $\operatorname{IgA}$ was seen in other volunteers. Conclusion: The administration of recombinant urease in $H$. pylori infected, asymptomatic adults is well tolerated. As expected, urease is not immunogenic in humans in the absence of an adjuvant. The safety of oral immunization with urease and an adjuvant is currently being tested in humans. (Supported by SNF 32-34369.92 and by a grant from OraVax, Inc. Cambridge, MA)

\section{B:02 IMMUNE RESPONSE TO HELICOBACTER PYLORI ANTIGENS IN INFECTED CHILDREN AND ADULTS}

M. Camorlinga-Ponce ', A. Escobar-Luján ' ${ }^{1}$ B. González-Ortiz ', A. Madrazo-De la Garza ${ }^{1}$, G. Pérez-Pérez ${ }^{2}$, O. Muñoz ${ }^{1}$, M. Dehesa ${ }^{1}$, J. Torres ${ }^{1}{ }^{1}$ Instituto Mexicano del Seguro Social, DF, México; ${ }^{2}$ Medicine-Vanderbilt University, Nashville, USA

$H$. pylori is clearly associated with gastritis, ulcers and gastric cancer. Few studies have investigated the immune response to the natural infection in children. The aim of this work was to study the serum IgA and IgG antibody response to different antigens of $H$. pylori in children infected with $H$. pylori and with chronic abdominal pain (CAP) and compared with the response observed in infected adults with duodenal ulcers (DU). Infection was assesed by biopsy, culture, and histology in all cases. Thirty one infected children, mean age $10.3 \pm 4.1$, and 35 infected adults, mean age $48 \pm 17.5$, were studied. ELISA was performed using as antigens: a pool of sonicate whole cells from three Mexican strains, a recombinant urease and a recombinant CagA protein (kindly supplied by OraVax, Inc.); all three assays were validated with known negative and positive sera to establish cut off values. Seropositivity in children with CAP, and adults with DU, respectively, were as follow: $64.5 \%$, and $100 \%$ for IgG sonicated extract; $9.7 \%$, and $53.6 \%$ for IgG urease; $25.8 \%$, and $71.4 \%$ for IgA urease; and $48.4 \%$, and $88.6 \%$ for IgG CagA. Among seropositive patients, adults had a significantly stronger response for IgG sonicate and IgA urease (mean of 7.0 and 3.3 ELISA units, respectively) than children (mean of 4.3 and 1.7 units respectively); however, children had a significantly stronger response for IgG CagA (mean of 6.4 units) than adults (mean of 4.3 units). CagAt strains seem to be more frequent in DU adults than in CAP children. The response to urease is inconsistent in both children and adults infected with H. pylori.

\section{B:03 THE 'SYDNEY STRAIN' OF H. PYLORI. A NEW STANDARD FOR VACCINE STUDIES IN MICE?}

F.J. Buck ${ }^{1}$, F.J. Radcliff ${ }^{1}$, J. O'Rourke ${ }^{1}$, A. Lee ${ }^{1}$, C. Doidge ${ }^{2}$.

${ }^{1}$ University of New South Wales, Sydney, Australia; ${ }^{2}$ CSL Ltd, Melbourne, Australia

Aim: A number of $H$. pylori strains capable of colonising mice have now been isolated, however these have not been well characterised and some strains show poor colonisation. Clearly there is a need for a better $H$. pylori mouse model. The new 'Sydney strain' isolated by our group has been shown to colonise mice with high infection levels, specific adhesion to gastric epithelial cells and pathology similar to that seen in humans. This study investigates the potential of this new, well characterised model as a tool for protective and therapeutic immunisation studies.

Method: Mice: SPF BALB/c. Vaccine: whole cell sonicate of $H$. pylori $(1 \mathrm{mg} /$ dose $)$ with cholera toxin (CT) $(10 \mu \mathrm{g} /$ dose). Infection/Challenge: $H$. pylori (SS1) in liquid culture, 3 doses over 5 days $\left(\approx 10^{8}\right.$ organisms/dose). Protective immunisation: mice were immunised (IG) on days $0,7,14$, and 21. 3 weeks post immunisation, animals were challenged with SS1. After a further 3 weeks infection was assessed. Therapeutic immunisation: mice were infected with SS1 for 2 months and then immunised (IG) on days 1 , $15,17 \& 20.1$ month post immunisation colonisation levels were assessed. Results:

\begin{tabular}{llll}
\hline Immunisation & Vaccine & \multicolumn{2}{l}{$\%$ H. pylori infection (no.) } \\
\cline { 3 - 4 } & & Urease assay & Histology \\
\hline Protective & H. pylori + CT & $10 \%(1 / 10)$ & $20 \%(2 / 10)^{*}$ \\
Protective & Saline & $80 \%(8 / 10)$ & $100 \%(10 / 10)$ \\
Therapeutic & H. pylori + CT & $37 \%(9 / 24)$ & in progress \\
Therapeutic & Saline & $88 \%(22 / 25)^{* *}$ & in progress \\
\hline
\end{tabular}

${ }^{*} \mathrm{p}<0.05,{ }^{* *} \mathrm{p}<0.001$ (Chi-square test)

Conclusion: Both protective and therapeutic immunisation were successful against $H$. pylori SS1, a strain known to colonise mice better than any other reported to date. This strain of $H$. pylori is now available to all those involved in vaccine studies. Hopefully its use will help standardise results between groups and facilitate selection of the final human vaccine.

1B:04 TOPICAL DUODENAL AND GASTRIC MUCOSAL PRODUCTION OF INTERLEUKIN-1 BETA, INTERLEUKIN-6, INTERLEUKIN-8, TUMOR NECROSIS FACTOR ALFA AND INTERLEUKIN-2-SOLUBLE RECEPTOR IN HELICOBACTER PYLORI POSITIVE AND NEGATIVE PATIENTS. A PILOT STUDY

J. Bureš, L. Plísková, P. Živný, S. Rejchrt, M. Šroký, V. Palička. Charles University Teaching Hospital, Hradec Králové, Czech Republic

Purpose of the study was to evaluate topical differences of mucosal cytokine production in H. pylori [HP] positive and negative patients.

Methods. Seventeen patients [6 men, 11 women, aged 21-74] entered the study. Five biopsy specimens for in vitro culture were taken from each person during routine gastroscopy: from duodenal bulb [DB], distal antrum [DA], proximal antrum, gastric corpus and fundus [GF]. HP positive status (7 patients) had both histology and CLO-testing positive, and vice versa in HP negative one (10 patients). Biopsy specimens were cultivated in RPMI medium for 23 hours. Cytokines were measured in homogenate supernatants by means of "sandwich" EIA using Quantikine kits $[R+D$ Systems]: interleukin-1 $\beta$ [IL-1 $\beta$ ], interleukin-6 [IL 6], interleukin-8 [IL8], tumor necrosis factor- $\alpha$ [TNF- $\alpha$ ] and interleukin-2-soluble receptor [sIL-2R]. Data were statistically treated [t-test, Mann-Whitney, StudentNewman-Keuls tests, PM ANOVA and Pearson Correlation] using Jandel Scientific.

Results are given as median (in $\mathrm{pg} / \mathrm{ml}$, except sIL-2R in $\mathrm{pM}, *$ significance $p=0.015$ ).

There was a correlation between antral IL- $1 \beta$ and IL- 6 ( $p<0.0001$ ), $\mathrm{IL}-1 \beta$ and TNF- $\alpha(\mathrm{p}<0.0001)$, IL-6 and IL-8 $(\mathrm{p}=0.0076)$. There was a correlation between fundal IL-6 and IL-8 $(p=0.0009)$. Duodenal sIL-2R production was significantly higher than antral one $(p=0.0038)$. 


\begin{tabular}{llrrrrr}
\hline & HP & IL-1 $\beta$ & \multicolumn{1}{c}{ IL-6 } & IL-8 & TNF- $\alpha$ & sIL-2R \\
\hline DB & pos & 7.59 & 22.40 & 22.11 & 1.580 & 7.63 \\
DB & neg & 4.75 & 9.12 & 0.00 & 1.560 & 11.70 \\
DA & pos & 23.35 & 19.90 & 371.40 & 4.065 & 3.44 \\
DA & neg & 7.97 & 20.70 & 222.00 & 0.720 & 3.39 \\
GF & pos & 11.19 & $50.50^{*}$ & 19.60 & 0.945 & 3.19 \\
GF & neg & 9.79 & 5.54 & 4.21 & 1.540 & 5.34 \\
\hline
\end{tabular}

Conclusions. A great deviation of values (both personal and topical difference) suggests the significance of several factors (including HP) influencing the consequent local inflammatory reaction.

\section{B:05 HELICOBACTER PYLORI (HP) CagA PROTEIN INDUCES A LYMPHOCYTE PROLIFERATIVE RESPONSE IN INFECTED SUBJECTS}

A. Tricerri, L. Guidi, D. Frasca ${ }^{1}$, M. Vangeli, M.E. Riccioni ${ }^{2}$, M. Costanzo, C. Bartoloni, R. Coppola ${ }^{2}$, G. Doria ${ }^{1}$, G. Gasbarrini. Ist. Clinica Medica e Geriatria, Roma, Italy; ${ }^{2}$ Patologia Chirurgica, Università Cattolica, Roma, Italy; ${ }^{1}$ Lab. Immunologia ENEA-CRE, Roma, Italy

$\mathrm{T}$ lymphocytes play a pivotal role in producing chemotactic factors, activating cytokines, driving a healing reaction and, over all, in determining the outcome of $\mathrm{Hp}$ infection. Aim of our study was to investigate if the lymphocytes obtained from peripheral blood (PBL) and those from gastric vein blood (GVBL) were able to proliferate to $\mathrm{Hp} \mathrm{CagA}$ protein and if this assay had any specificity in Hp infected patients. Patients supposed to undergo abdominal surgery (not for neoplastic or gastric diseases) underwent a thorough study for $\mathrm{Hp}$ infection. During the surgical intervention blood samples were obtained by puncture of the gastric draining veins and the antecubital vein. Lymphocytes were purified and cultured in the presence of several mitogenic stimuli (anti-CD3, anti-CD28, PHA, Hp CagA protein) and the proliferative response was measured by means of tritiated thymidine uptake. Hp CagA protein induced lymphocyte proliferative response in a high percentage of $\mathrm{Hp}$ infected subjects (71.5\% GVBL and 57\% PBL) while it did not in the Hp negative patients. Comparing the Hp positive and negative groups the mean lymphocyte proliferative response to CagA was significantly higher in the GVBL $(p<0.05$ ) while no difference was detected for the other mitogenic stimuli. Analyzing the patients as a whole, GVBL showed a significantly higher response to PHA than PBL. It is known that the Hp CagA protein can induce a humoral immune response. We have demonstrated that $\mathrm{T}$ lymphocytes from $\mathrm{Hp}$ infected subjects specifically proliferate in response to this antigen. Furthermore we detected a different functional behaviour of GVBL compared to PBL.

\section{B:06 PLATELET ENZYME ACTIVITIES BEFORE AND AFTER H. PYLORI INFECTION IN ASYMPTOMATIC VOLUNTEERS}

S.V. Nigdikar ${ }^{1}$, N.R. Williams ${ }^{1}$, A.N. Howard ${ }^{1}$, R.J. Dickinson ${ }^{2}$. ${ }^{1}$ Papworth Hospital, Cambridge, UK; ${ }^{2}$ Hinchingbrooke Hospital, Huntingdon, UK

Platelet cytochrome $\mathrm{c}$ oxidase (CCO) and superoxide dismutase (SOD) activities are copper status and antioxidant markers.

$\mathrm{CCO}$ (nmol/min/mg protein) and SOD (units $/ \mathrm{min} / \mathrm{mg}$ protein) activities were measured in washed platelets taken from asymptomatic volunteers before and after eradication of $\mathrm{H}$. pylori, if present (assessed by carbon-13 urea breath test, BSIA, UK). Results are shown in the Table.

Table. Effects of $H$. pylori Eradication on Platelet Enzyme Activities. Results shown as mean ( $95 \%$ confidence interval). Differences assessed by paired t-test.

\begin{tabular}{llllll}
\hline Enzyme & H. pylori & $\mathrm{n}$ & \multicolumn{2}{c}{ Eradicaton Therapy } & $\mathrm{P}$ \\
\cline { 3 - 6 } & & & Pre- & Post- & \\
\hline CCO & Positive & 8 & $5.7(5.0-6.5)$ & $9.3(5.9-12.8)$ & 0.02 \\
& Negative & 8 & $7.9(6.7-9.2)$ & $8.3(7.7-9.0)$ & NS \\
SOD & Positive & 6 & $65(35-95)$ & $225(88-362)$ & 0.04 \\
& Negative & 7 & $244(210-279)$ & $212(187-237)$ & NS \\
\hline
\end{tabular}

Volunteers with $H$. pylori infection had decreased CCO and SOD activities which normalised on treatment. This indicates that the decreased copper and antioxidant status associated with $H$. pylori infection can be corrected by successful eradication.

\section{B:07 MUCOSAL INTERLEUKIN-8, PLATELET-ACTIVATING FACTOR, ENDOTHELIN-1, LEUKOTRIENE $B_{4}$, AND LEUKOTRIENE $C_{4}$ PRODUCTION IN PATIENTS WITH} HELICOBACTER PYLORI INFECTION

V. Pasechnikov, E. Mashentseva, M. Soiher. Stavropol Medical State Academy, Stavropol, Russia

$H$. pylori synthesizes or causes very different cells to release a variety of inflammatory mediators (IM) which have been involved in patophysiology of chronic gastric inflammation. We investigated whether interleukin-8 (II8), platelet-activating factor (PAF), endothelin-1 (ET-1), and leukotrienes $\mathrm{B}_{4}$ and $\mathrm{C}_{4}\left(\mathrm{LTB}_{4}\right.$ and $\left.\mathrm{LTC}_{4}\right)$ are involved in the inflammatory reaction of $H$. pylori infection. Also, we investigated the effect of triple therapy on eradication of $H$. pylori and IM production. In 16 duodenal ulcer (DU) patients with $H$. pylori infection and 15 patients with negative urease test, serology and normal antral mucosa, the mucosal production of $\mathrm{IL}-8$, PAF, ET-1, $\mathrm{LTB}_{4}$, and $\mathrm{LTC}_{4}$ was measured in antral biopsy specimens after incubation in special conditions. The levels of $\mathrm{IM}$ appeared to be significantly higher in $H$. pylori-infected patients $\left(\mathrm{p}_{1--5}<0.05\right)$. IL-8, PAF, ET-1, LTB $_{4}$, and $\mathrm{LTC}_{4}$-production was significantly $\left(\mathrm{p}_{1--5}<0.05\right)$ decreased one month after eradication therapy (CBS $120 \times 4 \times 14$, AMO $500 \times 4 \times 14$, MET $250 \times 4 \times 14$, eradication rate $-90 \%$ ). A strong correlations were found between the production of IL-8 and PAF, PAF and $\mathrm{LTB}_{4}, \mathrm{ET}-1$ and $\mathrm{LTC}_{4}$, correspondingly. The biologic effects of these IM may explain recruitment, influx, and activation inflammatory cells in the gastric mucosa during $H$. pylori infection. Release of PAF and ET-1 might lead to occlusion in the microcirculation and affect epithelial integrity by ischaemic damage.

\section{B:08 INCREASED LEVELS OF SOLUBLE TUMOUR NECROSIS FACTOR RECEPTOR I (STNF RI) IN SERUM OF HELICOBACTER PYLORI-POSITIVE ISCHEMIC HEART DISEASE PATIENTS}

M. Neri, M. Reale, C. Di Febbo, D. Festi, A.M. Calafiore, P. Conti, F. Cuccurullo, E. Porreca. Università G. D'Annunzio, Chieti, Italy

Recent data suggest that Helicobacter pylori $(\mathrm{Hp})$ infection is an independent risk factor for Ischemic Heart Disease (IHD; Mendall et al, BHJ 1994; Patel et al, BMJ 1995). In this context, a possible role of a chronic systemic inflammatory response has been suggested, possibly mediated by cytokines such as TNF. This cytokine has been proposed as the physiologic stimulus for the release of its soluble receptors (sTNF RI and sTNF RII); in addition, sTNF RI has been demonstrated to circulate during experimental and clinical inflammation. Moreover, $\mathrm{Hp}$ induces the release and the expression of TNF in the gastric mucosa of infected patients (Moss et al, Gut 1994). Aim of the present study was to investigate the potential mechanisms of this association by evaluating serum concentrations of sTNF RI in Hp positive and Hp negative patients with IHD in comparison to a control population. Methods: 29 male patients with IHD scheduled for coronary by-pass surgery (mean age $49 \pm 9$, range 38-65) were age and sex matched to a control population of 11 subjects without IHD (mean age $46 \pm$ 8 range 40-65) after controlling for other risk factors (smoke, diabetes, hypertension, serum cholesterol). In patients and subjects the presence of $\mathrm{Hp}$ infection was assessed by means of serum anti-Hp IgG and ${ }^{13} \mathrm{C}$ urea breath test and considered Hp negative when both tests were negative. sTNF RI levels were assayed by ELISA using a commercial kit. Results: Data are shown in the following table:

\begin{tabular}{llll}
\hline & Hp positive & Hp negative & Total \\
\hline IHD & $1877+138(n=19)^{\circ}$ & $1274+125(n=10)$ & $1674+107^{*}$ \\
Controls & $1196+152(n=5)$ & $961+74(n=6)$ & $1078+113$ \\
\hline
\end{tabular}

${ }^{*} \mathrm{p}<0.01$ vs controls, $\mathrm{t}$-test; ${ }^{\circ} \mathrm{p}<0.01$ vs Hp negative IHD and controls (ANOVA with Tukey's test)

Summary: Hp infection is associated to a systemic release of the RI soluble receptor for TNF. IHD patients showed significantly increased serum levels of sTNF RI with respect to controls. sTNF RI levels were significantly increased in $\mathrm{Hp}$ positive IHD patients with respect to Hp negative IHD patients and both control groups. Conclusion: Our data suggest that the previously observed association between $\mathrm{Hp}$ infection and IHD might be explained through a TNF-mediated inflammatory mechanism elicited by chronic bacterial infection. 


\section{B:09 BASOPHIL HISTAMINE RELEASE STIMULATED BY HOMO- AND HETEROLOGOUS STRAINS OF HELICOBACTER} PYLORI

H. Permin ${ }^{1}$, H. Nielsen ${ }^{1}$, L.P. Andersen ${ }^{1}$, L. Elsborg ${ }^{2}$, A. Nørgaard ${ }^{1}$. ${ }^{1}$ University Hospital, Rigshospitalet, Copenhagen, Denmark; ${ }^{2}$ Hillerød Hospital, Hillerød, Denmark

Introduction: It has been described that Helicobacter pylori $(H p)$ positive patients have reduced gastric histamine concentrations compared to $\mathrm{Hp}$ negative controls. It was proposed that this was due to an increased liberation of histamine from mastcells in the $H p$ infected gastric mucosa.

Aim: The study was performed to elucidate whether there is a type 1 hypersensitivity reaction against homo- and heterologous $\mathrm{Hp}$ strains using basophil histamine release.

Materials and methods: 64 consecutive patients were included in the study. Thirtythree were $H p+$ assessed by culture. The 33 strains were isolated and bacterial sonicates were made. Isolated basophils from the patients were stimulated with anti-IgE, a heterologous strain and, if the patient was $H p+$, with the homologous strain as well. Histamine release was determined spectrofluorometrically and expressed in percent of total histamine content. A release less than $10 \%$ was considered to be negative.

Results: When stimulating basophils from the $33 \mathrm{Hp}+$ patients the mean peak histamine release was $(13 \pm 1) \%$ when stimulating with the homologous strain, compared to $(6 \pm 1) \%$ with the heterologous strain. Comparing the $\mathrm{Hp}+\mathrm{vs} \mathrm{Hp}$ - when stimulating basophil histamine release with the heterologous strain mean peaks were $(6 \pm 1) \%$ vs $(5 \pm 1) \%$.

Conclusions: There is a type 1 hypersensitivity reaction against homologous $\mathrm{Hp}$ strain. The basophil histamine release was significantly higher when stimulating with the homologous strain than the heterologous strain $(p<0.0001)$. The histamine release was IgE-mediated. There were no difference in histamine release between the $H p+$ and $H p$ - group of patients when stimulating with the heterologous strain.

\section{B:10 EVIDENCE THAT CORPORAL LYMPHOID FOLLICLES (LF) DO NOT DISCRIMINATE AUTOIMMUNE OR H. PYLORI RELATED CHRONIC ATROPHIC GASTRITIS (CAG)}

M. Marignani, P. Caruana ${ }^{1}$, B. Annibale, S. Angeletti, G. Antonelli, G. Delle Fave, C. Bordi ' . University "La Sapienza" Roma, Italy;

1 University "La Sapienza" Parma, Italy

CAG is a condition characterized by atrophy of oxyntic mucosa hypo/achlorhydria and fasting hypergastrinemia. It has been considered an autoimmune condition, usually associated with latent or overt pernicious anemia (PA), but it has recently been observed that a small proportion of CAG patients are $\mathrm{Hp}$ infected. However, since the progression of corporal gastritis is accompanied by disappearance of $H$. pylori, the persistence of immunological memory, expressed by the presence of IgG to $\mathrm{Hp}$, could indicate past exposure to the bacterium. Presence of LF in gastric biopsy specimens have been described as a constant feature of $\mathrm{H}$. pylori-associated gastritis. Aim of this study was to investigate in a consecutive series of newly diagnosed CAG patients, the prevalence of present or past infection and the presence of $L F$ as a histological marker of $H$. pylori infection. 104 consecutive hypergastrinemic CAG patients (84 F, $20 \mathrm{M}$ aged 22-81) divided in three groups as follows: Histo $-=$ histology, culture, IgG negative. Histo+ $=$ histology, colture, IgG; at least two of these tests positive. IgG $+=$ histology and colture negative, only IgG positive ( $>40 \mathrm{U} /$; Elisa, Biorad). Corporal atrophy was defined as focal or complete replacement of oxyntic glands by metaplastic pyloric or intestinal glands. LF were defined as intramucosal, basally located lymphoid aggregates with or without germinal centers.

\begin{tabular}{lll}
\hline CAG Groups & \multicolumn{2}{c}{ \% Positive lymphoid follicles } \\
\cline { 2 - 3 } & Antrum & Corpus \\
\hline Histo- $(\mathrm{n}=58 ; 55.8 \%)$ & 16.7 & 52.8 \\
Histo+ $(\mathrm{n}=25 ; 24 \%)$ & $50^{*}$ & 70 \\
$\mathrm{IgG}+(\mathrm{n}=21 ; 20.2 \%)$ & 5.9 & 61.9 \\
\hline
\end{tabular}

Results: In a consecutive, newly diagnosed series of CAG patients, autoimmunity accounts for $55.8 \%$, whereas active or past $\mathrm{H}$. pylori infection for $44.2 \%$. Corporal LF are widely present but do not discriminate the two different ethiologic causes. In the antrum of Histo+ pts, LF are present in the $50 \%$, being significantly higher than the other two groups ${ }^{*}$ Fisher test $p<0.005$ ) Conclusions: These data show that $44.2 \%$ of CAG pts have been infected $\mathrm{H}$. pylori and that corporal LF are not exclusive markers for the presence of the infection.
1B:11 CHEMILUMINESCENT IMAGING OF INDUCIBLE NITRIC OXIDE SYNTHASE IN THE GASTRIC EPITHELIUM IN $H$. PYLORI INFECTION AND GASTRIC CANCER

J.E. Crabtree, P. Pasini ${ }^{1}$, F. Bazzoli ${ }^{1}$, J.I. Wyatt, E. Roda ${ }^{1}$, A. Roda ${ }^{1}$. St. James's Hospital, Leeds, UK; ${ }^{1}$ University of Bologna, Italy

Purpose. Increases in inducible nitric oxide synthase (iNOS) are associated with intestinal inflammatory conditions. Products of NO, such a peroxynitrite, may be important mediators of mucosal damage but NO may also contribute to mucosal defence. This study investigates quantitatively iNOS protein and tyrosine nitrated proteins in the gastric epithelium of patients with chronic gastritis and gastric cancer by immunochemiluminescence.

Methods. Cryosections of antral biopsies $(n=23)$ or resected gastric mucosa from non-neoplastic areas $(n=9)$ were incubated with rabbit antiiNOS antibody, normal rabbit serum and anti-nitrotyrosine monoclonal antibody. Bound antibodies were detected using a low light imaging luminograph following incubation with peroxidase and phosphatase labelled second antibodies and substrate.

Results. 14/18 (78\%) $\mathrm{HP}^{+}$patients with chronic gastritis, $1 / 5(20 \%) \mathrm{Hp}^{-}$ with normal histology and $7 / 9(78 \%)$ of the cancer patients had a positive chemiluminescent signal for iNOS in the epithelium. No signal was detected in epithelial cells with control rabbit sera. Median (IQR) iNOS levels were respectively $42.6(10.8-66.4)$ photons/sec/unit area $\left(\mathrm{HP}^{+}\right), 0(0-22.1)$ $\left(\mathrm{HP}^{-} ; \mathrm{p}<0.05\right.$ versus $\mathrm{HP}^{+}$) and $32.1(11-64)$ in cancer patients. In $\mathrm{HP}^{+}$ patients 7/8 CagA seronegatives and 7/10 CagA seropositives were iNOS positive. Median iNOS values were 48.1 (21.7-72.9) (CagA neg) and 41.3 (0-63) (CagA pos). Focal areas of nitrotyrosine staining in epithelial cells were observed in $3 / 18 \mathrm{HP}^{+}, 2 / 9$ cancer patients but in no $\mathrm{HP}^{-}$patients.

Conclusions: Sensitive chemiluminescence techniques can quantitatively detect iNOS in gastric epithelial cells. Infection with CagA pos and CagA neg $H$. pylori strains is associated with increased iNOS in the epithelium which in some cases results in peroxynitrite formation.

\section{B:12 ACTIVATION OF T CELL SUBSETS IN THE PERIPHERAL BLOOD AND THE GASTRIC MUCOSA IN H. PYLORI (HP) INFECTION}

S. Birkholz, U. Knipp ', M. Salamon-Looijen ${ }^{2}$, G. Feifel ${ }^{3}$, T. Schneider, A. Stallmach, M. Zeitz. ${ }^{2}$ Med. Clinic II, Dept. Pathol., University of the Saarland, Homburg, Germany; ${ }^{3}$ Dept. Surgery, University of the Saarland, Homburg, Germany; ' ${ }^{1}$ Med. Microbiol. Immunol.,

Ruhr-University Bochum, Germany

In this study we investigated the activation of mucosal $\mathrm{T}$ lymphocytes in $\mathrm{Hp}$ infection in comparison to lymphocytes of uninfected mucosa. To determine the influence of $\mathrm{Hp}$ antigens on the activation of peripheral and mucosa-associated mononuclear cells (PBMC/MAMC), isolated lymphocyte populations were stimulated with $\mathrm{Hp}$ antigens in vitro. Methods: PBMC of Hp positive blood donors were isolated by ficoll density gradient. MAMC were isolated from macroscopically unaffected antral mucosa of gastric carcinoma patients who underwent gastric resection. MAMC and Hp stimulated PBMC were characterised by three colour flow cytometry. Hp specific activation was determined by proliferation tests. Results: More CD3+ mucosal lymphocytes of $\mathrm{Hp}+$ patients were CD4+ (CD4/CD8 ratio: $\mathrm{Hp}+1.2, \mathrm{Hp}-0.3)$ and expressed CD25 marker in a higher percentage compared to $\mathrm{Hp}-$ patients $(\mathrm{Hp}+8.5 \%, \mathrm{Hp}-3.3 \%)$. $\mathrm{CD} 25$ was expressed by CD4+ as well as CD8+ cells but the CD4/CD8 ratio of activated cells showed a shift in favour of CD8+ T cells ( Hp- 4.5, Hp+ 2.6). No differences were found between the two patient groups concerning the expression of HLADR. PBMC as well as MAMC of $\mathrm{Hp}+$ patients proliferated well after stimulation with PHA, tuberkuline, and IL-2. MAMC of only two out of six patients proliferated after Hp stimulation. In contrast PBMC in five out of six patients proliferated after Hp stimulation. Both $\mathrm{CD} 4+$ and $\mathrm{CD} 8+\mathrm{T}$ cells in PBMC expressed activation markers after antigen stimulation (table, median \%). Conclusion: The finding of a poor proliferation response of MAMC indicates differences in responsiveness of peripheral and mucosal $\mathrm{T}$ cells. Although more mucosal CD4+ $\mathrm{T}$ cells in Hp infection were observed, both CD4+ and CD8+ T cells are activated. There was even an increase in the relative number of activated CD8+ T cells.

\begin{tabular}{|c|c|c|c|c|c|c|}
\hline & \multicolumn{2}{|c|}{ HLADR + } & \multicolumn{2}{|c|}{ CD25 + } & \multicolumn{2}{|c|}{ CD71 + } \\
\hline & $\overline{\mathrm{Hp}}$ & Med. & $\overline{\mathrm{Hp}}$ & Med. & $\overline{\mathrm{Hp}}$ & Med. \\
\hline $\begin{array}{l}\text { CD3/CD4+ } \\
\text { CD3/CD8+ }\end{array}$ & $\begin{array}{l}10.4 \\
13.7\end{array}$ & $\begin{array}{l}4.0 \\
5.7\end{array}$ & $\begin{array}{l}9.8 \\
9.9\end{array}$ & $\begin{array}{l}7.4 \\
3.2\end{array}$ & $\begin{array}{l}6.4 \\
7.4\end{array}$ & $\begin{array}{l}3.2 \\
2.3\end{array}$ \\
\hline
\end{tabular}




\section{B:13 H. PYLORI-SPECIFIC TH1 EFFECTOR CELLS IN THE GASTRIC ANTRUM OF PATIENTS WITH PEPTIC ULCER DISEASE}

G. Del Prete, M.M. D'Elios, M. Manghetti ${ }^{~}$, S. Romagnani, J.L. Telford ${ }^{2}$ University of Florence; ${ }^{1}$ University of Pisa; ${ }^{2}$ IRIS-Biocine, Siena, Italy

Infection of the gastric antrum by $H$. pylori (Hp) is characterized by a cellular inflammatory infiltrate which is thought to play a role in the pathogenesis of peptic ulcer. The nature of cytokines produced during the immune response to $\mathrm{Hp}$ may represent a host-dependent factor able to influence the outcome of the infection. To analyze the pattern of cytokines produced by the immunologically active cells within the gastric antrum, cytokine mRNA expression was studied in antral biopsies from $5 \mathrm{Hp}$-infected patients with duodenal ulcer and $3 \mathrm{Hp}$-negative dyspeptic controls. T-cell clones were also generated from parallel samples of antral mucosa of the same Hp-infected patients and assessed for their reactivity to Hp antigens, profile of cytokine secretion, and effector functions. Antral biopsies from all Hp-infected patients showed IFN- $\gamma$, TNF- $\alpha$, IL-12, but not IL-4, mRNA expression, whereas no cytokine mRNA signal was found in the mucosa of $3 \mathrm{Hp}$-negative controls. When assayed for their responsiveness to a Hp lysate, 24 out of the $163 \mathrm{CD}^{+}{ }^{+}$T-cell clones $(15 \%)$ derived from $\mathrm{Hp}$-infected patients proliferated in response to Hp lysate. Eleven clones (46\%) reacted with Cag-A, 2 with Vac-A, and 1 with Urease.

Upon $\mathrm{Hp}$ antigen stimulation, the great majority of Hp-reactive clones (20/24) produced IFN- $\gamma$, but not IL-4 or IL-5 (Th1-like), whereas 4 produced both IFN- $\gamma$, and IL-4 and IL-5 (Th0-like). In addition, all Hp-specific clones secreted high amounts of TNF- $\alpha$. At low T/B cell ratio, Hp-specific clones expressed antigen-dependent helper function for B-cell proliferation and immunoglobulin production, whereas at higher T/B cell ratios, $15 \mathrm{Th} 1$ and 2 Th0 clones lysed antigen-pulsed autologous EBV-transformed B cells.

These results demonstrate the presence of Hp-specific Thl effector cells in the gastric antral mucosa of $\mathrm{Hp}$-infected patients. These cells may play a role in the pathogenesis of both peptic ulcer and gastric B-cell lymphoma associated with $\mathrm{Hp}$ infection.

\section{B:14 VACCINATION OF GNOTOBIOTIC PIGLETS AGAINST $H$.
PYLORI}

\section{K.A. Eaton, S. Krakowka. Ohio State University, Columbus OH, USA}

Parenteral vaccination with bacterial antigen fails to protect piglets against challenge with $H$. pylori, but results in increased severity of gastritis. In contrast, oral vaccination with bacterial antigen and cholera toxin protects mice against challenge with $H$. felis. To determine the effect of oral adjuvant in piglets, we vaccinated piglets parenterally and orally and evaluated their response to oral challenge with live $H$. pylori.

Four vaccination regimens were used: Subcutaneous vaccination with bacterial antigen in Freund's adjuvant; oral vaccination with bacterial antigen alone; oral vaccination with bacterial antigen and $E$. coli labile toxin (LT); and oral administration of sterile brucella broth (unvaccinated controls). Piglets were vaccinated 3 times at weekly intervals, challenged with live $H$. pylori 1 week after the last vaccination, and killed 1 or 2 weeks after challenge. Bacterial colonization was quantified, tissues were examined histologically, and serum and gastric secretions were collected for antibody determination.

All groups of piglets became infected with $H$. pylori. Groups vaccinated either parenterally or orally with LT had lower levels of colonization than unvaccinated piglets or piglets vaccinated without adjuvant, but the rate of colonization varied widely $\left(10^{3} \mathrm{cfu} / \mathrm{g}\right.$ to $\left.10^{6} \mathrm{cfu} / \mathrm{g}\right)$ and group differences were not statistically significant. All piglets developed IgA and lymphocytic inflammation, but only piglets vaccinated parenterally and piglets vaccinated orally with LT had IgG and neutrophilic inflammation.

Like parenteral vaccination, oral vaccination fails to protect piglets against challenge with live $H$. pylori, even when $\mathrm{LT}$ is used as an adjuvant. Both parental and adjuvant-assisted oral vaccination appear to diminish colonization, but both induce neutrophilic inflammation in some piglets.

\section{B:15 IL-10 INHIBITS H. PYLORI INDUCED NEUTROPHIL BUT NOT EPITHELIAL CHEMOKINE SECRETION}

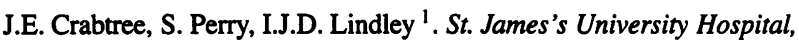
Leeds, UK; ' Sandoz Research Institute, Vienna, Austria

Purpose. In $H$. pylori infection, gastric mucosal expression of proinflammatory cytokines (II-1, TNF- $\alpha$, IL-8) and down-regulatory cytokines (IL-10) is increased. $H$. pylori directly induces neutrophils and gastric epithelial cells to secrete IL-8 in vitro. IL-10 inhibits the neutrophil chemokine production induced by cytokines or LPS stimulation. This study investigates the inhibitory effects of IL-10 on $H$. pylori induced neutrophil and epithelial IL-8 secretion.
Methods. Peripheral blood neutrophils were cultured at $2 \times 10^{6} / \mathrm{ml}$ for 24 hours with $5 \times 10^{7}$ heat killed $H$. pylori (NCTC 11637) with or without IL-10 or IL-13 (1-100 ng/ml). Kato-3 gastric epithelial cell $5 \times 10^{5} / \mathrm{ml}$ were cultured with viable CagA positive NCTC 11637 (bacteria:cell 100:1) for 24 hours with or without IL-10 or IL-13. Cell supernatants were assayed for secreted IL- 8 by ELISA.

Results. Neutrophil IIL-8 secretion was strongly induced by co-culture with $H$. pylori (mean $\pm \mathrm{SE}, 13.7 \pm 0.51 \mathrm{ng} / \mathrm{ml}$, control $0.56 \pm 0.41, \mathrm{n}=$ 3). Co-culture in the presence of IL-10 decreased IL-8 secretion in a dose dependent fashion; reduction at $1 \mathrm{ng} / \mathrm{ml}(14 \%), 10 \mathrm{ng}(55 \%), 50 \mathrm{ng}(74 \%)$, $100 \mathrm{ng} / \mathrm{ml}(80 \%)$. In contrast to IL-10, IL-13 had no effect on H. pylori stimulated neutrophil IL-8 secretion. The gastric epithelial cell line Kato-3 secreted IL-8 in response to $H$. pylori, $5.8 \pm 2.1 \mathrm{ng} / \mathrm{ml}(\mathrm{n}=3)$. Co-culture with IL-10 or IL-13 over a 1 to $100 \mathrm{ng} / \mathrm{ml}$ range had no effect $H$. pylori induced epithelial IL-8 secretion.

Conclusions: Whilst direct stimulation of neutrophil chemokine secretion by $H$. pylori may amplify mucosal neutrophil recruitment, IL-10 can down regulate this inflammatory cascade. In contrast to the effect of IL-10 on neutrophils, the induction of IL-8 in gastric epithelial cells by $H$. pylori could not be inhibited by IL-10

\section{B:16 OXIDATIVE BURST AND RELEASE OF CONSTITUENTS OF PRIMARY AND SECONDARY GRANULES FROM NEUTROPHILS ACTIVATED BY HELICOBACTER PYLORI. SURVIVAL OF PHAGOCYTOSIS}

M. Hagman ${ }^{1}$, M. Jurstrand, D. Danielsson. ${ }^{1}$ University College of Värmland, Karlstad, Sweden; Örebro Medical Center Hospital, Sweden

Background and objectives: Chemotaxis by $H$. pylori and II-8 produced by gastric epithelial cells in infected and inflamed areas attracts large numbers of neutrophils to the gastric mucosa, a crucial part of active chronic gastritis. The aims of the present investigations were to study the oxidative burst (chemiluminescence, $\mathrm{Cl}$ ), and the release of constituents of primary (myeloperoxidase, MPO) and secondary (lactoferrin, Lf) granules from neutrophils during phagocytosis of cytotoxin (ct) and noncytotoxin (nct) producing H.p. strains, nonopsonized (nonops) or opsonized (ops).

Methods: H.p. NCTC 11637 (ct with rapid and strong CL when nonops), and C-7050 (nct with weak and slow CL when nonops) were used Neutrophils isolated by Ficoll-Paque were stimulated by nonops or ops organisms of H.p., the oxidative burst measured by CL the release of MPO by radioimmune assay, and Lf by ELISA.

Results: Release from neutrophils of $60-100 \%$ of Lf but $<7 \%$ of MPO occurred within 30-60 min after they were activated with nonops H.p. 11637. Corresponding experiments with C-7050 gave a release of $14-47 \%$ of Lf and $<7 \%$ of MPO. When ops, both strains activated neutrophils to a strong and rapid release of $100 \%$ of $\mathrm{Lf}$ within $15-30 \mathrm{~min}$ and $15-20 \%$ of MPO. Nonops 11637 were rapidly phagocytosed (within $5 \mathrm{~min}$ ) whereas C-7050 with a weak and slow CL were not. When ops both strains activated neutrophils to oxidative burst and were rapidly phagocytosed and killed. Nonops H.p. 11637 survived phagocytosis for $>24$ hours.

Conclusions: The rapid and strong activation of neutrophils by nonops H.p. leads to phagocytosis and complete release of $\mathrm{Lf}$ but very little of MPO which may explain the survival of nonops H.p. after phagocytosis.

\section{B:17 HELICOBACTER PYLORI SPECIFIC B-CELLS IN GASTRIC MUCOSA}

A. Mattsson, M. Quiding-Järbrink, I. Ahlstedt, A. Hamlet, H. Lönroth, A.-M. Svennerholm. Göteborg University, Göteborg, Sweden

Purpose: The aim of this study was to evaluate the presence of $H$. pylori specific antibody secreting cells (ASCs) in gastric mucosa of asymptomatic $H$. pylori carriers and duodenal ulcer (DU) patients.

Methods: Five $H$. pylori infected patients with DU, five asymptomatic $H$. pylori carriers and nine healthy, non-infected subjects were gastroscoped and 10 biopsies were taken from the antrum and corpus, respectively, of each subject. Mononuclear cells were isolated by means of enzymatic dispersion and tested for specificity against different $H$. pylori antigens, i.e. membrane proteins (MP), flagellin and urease, by the ELISPOT-assay.

Results: None of the non-infected subjects had ASCs that were specific for any of the antigens tested. On the contrary, all of the infected subjects had high numbers of ASCs against flagellin and most of them also had urease and MP specific ASCs. Furthermore, the infected subjects had approximately 20 times more total IgA secreting cells than the non-infected subjects while the frequency of IgG and IgM secreting cells were similar between the two groups. No difference in antigen specificities has been noted between symptomatic and asymptomatic $H$. pylori carriers so far.

Conclusions: $H$. pylori induces strong antibody responses locally in the stomach, especially against flagellin and urease, in symptomatic as well as asymptomatic individuals. 


\section{B:18 IN SITU DETECTION OF CYTOKINES IN H. PYLORI-INFECTED}

C.M. Lindholm, M. Quiding-Järbrink, H. Lönroth, A.K. Hamlet, A.-M. Svennerholm. Göteborg University, Sweden

Aim: To identify and localize the cytokines produced in $\mathrm{H}$. pylori-infected. Methods: An indirect immunohistochemical technique was used to determine the production and localization of $\Pi \mathrm{L}-1 \beta, \mathrm{IL}-6, \mathbb{L}-8, \mathrm{~F} N-\gamma$, TNF- $\alpha$ and TGF- $\beta$ at the single-cell level in cryopreserved antral biopsies from $H$. $p$-positive duodenal ulcer patients $(n=6)$ and healthy controls $(n$ $=6$ ).

Infection was diagnosed by cultivation, serology and/or urea breath test. H. $p$-density and gastritis (presence of chronic inflammatory cells and neutrophils) was graded by histopathological examination.

Results: All infected individuals had moderate to severe chronical antral gastritis whereas the biopsies from the healthy subjects were normal.

IL-6, IL-8 and IFN- $\gamma$ production was detected in all $H$. p-positive subjects and in 5 of 6,1 of 6 and 2 of 6 , respectively, of the controls. II -6 was intensely stained in the infected individuals whereas there was a very weak reaction in the controls. TGF- $\beta$ and IL- $1 \beta$ was found in 5 of 6 of as well the controls as the $H$. p-positive subjects. 5 of 6 infected showed positive staining for TNF- $\alpha$ as compared to 2 of 6 controls. IL-6, IFN- $\gamma$ and TGF- $\beta$ were detected in surface epithelial cells, gastric pits, intraepithelial lymphocytes and mononuclear cells in the lamina propria whereas IL-1 $\beta$, IL-8 and TNF- $\alpha$ showed immunoreactivity for the 3 latter cell types only.

Conclusions: The inflammatory response to $H$. pylori-infection is characterized by an increased antral production of IL-8, IFN- $\gamma$ and TNF- $\alpha$.

\section{B:19 CYTOKINE INDUCTION BY PURIFIED H. PYLORI ANTIGENS}

M. Quiding-Järbrink, A.-M. Svennerholm. Department of Medical Microbiology and Immunology, Göteborg University, Göteborg, Sweden

Aim: The aim of this study was to characterize the cytokine response to stimulation of human mononuclear cells (MNC) with purified $H$. pylori antigens, in order to determine which antigens that induce inflammatory responses and $\mathrm{T}$ cell activation.

Methods: MNC were purified from blood collected from $H$. pylori infected and non-infected volunteers. Isolated cells were cultured in the presence of purified $H$. pylori urease, flagellin, membrane proteins (MP), LPS and recombinant $30 \mathrm{kD}$ protein. Cell culture supernatants were collected after 24 and 48 hours and the concentration of IL-4, IFN- $\gamma$, IL-10, IL-12, IL-8, and TNF- $\alpha$ was determined in ELISA assays.

Results: Stimulation with the MP fraction induced large amounts of IL-8, TNF- $\alpha$ and IFN- $\gamma$. Likewise, stimulation with urease and the 30 $\mathrm{kD}$ protein also induced high levels of IL-8, TNF- $\alpha$ and IFN- $\gamma$, although not as high as those induced by MP. In contrast, flagellin only induced very low levels of any cytokine tested. $H$. pylori LPS induced secretion of IL-10 and TNF- $\alpha$, but not to the same extent as E. coli LPS. On the other hand, $H$. pylori LPS was as good, or even better, as $E$. coli LPS in inducing IL-8-production. IL-4, IL-10, and IL-12 were virtually never seen after stimulation with any of the antigens, except for the IL-10 production after LPS stimulation. These cytokines could, however, be detected after polyclonal stimulation.

Conclusion: Purified $H$. pylori antigens preferentially induce production of IFN- $\gamma$, TNF- $\alpha$, and IL-8, cytokines that promote cell-mediated inflammatory reactions. The action of these cytokines could partially be responsible for the local inflammation in the $H$. pylori infected stomach

\section{B:20 IMMUNIZATION AGAINST NATURAL HELICOBACTER PYLORI INFECTION IN RHESUS MONKEYS}

A. Dubois ${ }^{1}$, C. Lee ${ }^{2}$, N. Fiala ${ }^{1}$, H. Kleanthous ${ }^{2}$, T. Monath ${ }^{2}$. ${ }_{1}^{1}$ USUHS and AFRRI, Bethesda, MD, USA $;{ }^{2}$ OraVax, Inc., Cambridge, $M A, U S A$

We have observed that $H$. pylori infection was widespread in a rhesus monkey colony, that $71 \%$ of the females were infected early in life, and that the rate of seroconversion was $28 \%$ /year in that population (J Clin Microbiol 1995; 33: 1492). We hypothetized that such a population was ideal to test the safety and efficacy of an anti-H. pylori vaccine. A group of nine-month-old female monkeys was selected to receive randomly and blindly either $20 \mathrm{mg}$ recombinant urease (rUre) $+5 \mu \mathrm{g} E$. coli heat-labile enterotoxin (LT) $(n=26)$ or LT alone $(n=29)$. rUre and/or LT was sprayed on the back of the throat of ketamine-anesthetized animals three times at one-week intervals. No side effects were observed in any of the animals receiving either rUre + LT or LT alone. Eleven months later, the animals were gastroscoped under anesthesia and mucosal biopsies were either fixed and H\&E- and Genta-stained (4 biopsies/animal), or cultured (5 biopsies/animal). H. pylori infection, as assessed by culture and/or histology, was present in 93\% (27/29) of animals receiving LT alone but in only $65 \%(17 / 26)$ of animals receiving rUre + LT $(p=0.049$ by Fisher's exact test). Among animals given rUre $+\mathrm{LT}$, the gastritis score was lower in $H$. pylori-negative than in $H$. pylori-positive animals, and a similar finding was observed in animals given LT alone. In addition, quantitative cultures did not demonstrate significant differences between $H$. pylori-positive animals that had been immunized, and those who received LT alone. This latter finding indicates that previous immunization with rUre does not significantly modify the extent of colonization of $H$. pylori-infected monkeys. Since our previous studies suggest that a large proportion of the animals were already $H$. pylori positive before immunization was performed, oral administration of rUre vaccine combined with LT appears to confer protective immunity to uninfected animals while not causing undesirable side effects.

\section{B:21 T-CELL RESPONSES TO H. PYLORI: ACTIVATION AND IFN- PRODUCTION BY CD4+ AND CD8+ LYMPHOCYTES IN THE PERIPHERAL AND GASTRIC COMPARTMENTS}

K.B. Bamford ${ }^{2}$, S.E. Crowe, X.J. Fan, E. Brooks, V.E. Reyes,

D.Y. Graham ' , P.B. Ernst. Depts of Internal Medicine and Pediatrics, University of Texas Medical Branch, Galveston, TX, USA; ${ }^{1}$ VA Medical Center, Houston, TX, USA $;^{2}$ QUB, Belfast, N. Ireland

It is known that there is an increase in the numbers of CD4+ and CD8+ lymphocytes in the gastric mucosa during $H$. pylori infections and that peripheral blood mononuclear cells (PBMCs) proliferate in response to this organism. It is interesting that the proliferative responses of PBMCs from $H$. pylori negative donors in greater than that of PBMCs of $H$. pylori positive donors. The early activation marker CD69 is maximally expressed 24 hours after cellular activation events and correlates closely with proliferative responses. Use of this parameter in three colour flow cytometric analysis allows the investigation of the relative activation of CD4+ and CD8+, CD3+ cells in response to the same stimulus. PMBCs were purified from 5 seropositive or seronegative asymptomatic individuals and stimulated with a heat inactivated preparation of a clinical isolate of H. pylori which was previously shown to produce a significant proliferative response. $H$. pylori stimulation resulted in the activation (increased CD69 expression) of both CD3+CD4+ and CD3+CD8+ peripheral blood lymphocytes. Although the production of interferon- $\gamma$ (IFN- $\gamma$ ) has been described in gastric cells, the specific association with $T$ cells has not been determined. To characterize the gastric T cells, lymphocytes were isolated from the intraepithelial and lamina propria compartments of biopsies from infected patients. Cells were stimulated in the presence of monensin to block protein export for 4 hours and stained with fluorescent conjugated anti-human CD3, CD4 and CD8, permeabilised and then stained with anti-IFN- $\gamma$ to detect intracellular cytokine. IFN- $\gamma$ production was detected in both $\mathrm{CD} 3+\mathrm{CD} 8+$ and $\mathrm{CD} 3+\mathrm{CD} 4+$ gastric $\mathrm{T}$ cells although more $\mathrm{CD} 8+$ $\mathrm{T}$ cells expressed this cytokine than the $\mathrm{CD} 4+\mathrm{T}$ cells. These data provide direct evidence that natural infection with $H$. pylori activates the Thl subset in gastric tissue. Abrogation of IFN- $\gamma$-producing $\mathrm{CD} 8+\mathrm{T}$ cells by mucosal adjuvants such as cholera toxin or use of antigens which are more selective of a Th2 type of response may be appropriate in vaccine design.

\section{B:22 DNA IMMUNIZATION DECREASES THE LEVEL OF INFECTION IN THE FELIS-MOUSE MODEL, IRRESPECTIVE OF THE TITER OF SPECIFIC ANTIBODIES}

I. Corthésy-Theulaz, B. Corthésy ${ }^{2}$, D. Bachmann, N. Porta, A.-C. Vaney ${ }^{1}$, E. Saraga ${ }^{1}$, P. Michetti, J.-P. Kraehenbuhl ${ }^{2}$, A.L. Blum. Division of Gastroenterology, CHUV, Lausanne, ' Pathology Institute, Lausanne University, ${ }^{2}$ Biochemistry Institute and ISREC, Epalinges, Switzerland

DNA immunization consists of injections of DNA in muscles that lead to a sustained antigen production by the host. This process induces potent humoral and cellular immune responses against the antigen encoded by the DNA. The aim of this study was to test whether DNA immunization with Helicobacter pylori $(H p)$ urease genes induces antibody responses in the mouse and confers protection against Helicobacter felis $(H f)$ infection.

Methods: The A and B subunits of $H p$ urease were cloned into a mammalian expression vector. Each gene was demonstrated to function in Cos-1 cells. Specific pathogen free BALB/c female mice were immunized 5 times at one week intervals with $100 \mu \mathrm{g}$ of plasmid DNA encoding the $H p$ urease A (pUreA) or the $H p$ urease B subunit (pUreB). A third group received $50 \mu \mathrm{g}$ of each pUreA and pUreB. Plasmid DNA was injected, into the quadriceps muscle. Control mice were not immunized. One month later, animals were infected with $10^{7} \mathrm{Hf}$. After 4 weeks, presence of $\mathrm{Hf}$ was assessed in gastric biopsies by rapid urease test (OD measured at 550 $\mathrm{nm}$ ) and by histology. Levels of seric antibodies against $H p$ urease were monitored by ELISA 10 days after the last immunization (imm.) and two weeks after infection (inf.). 
Results:

\begin{tabular}{lllllll}
\hline Plasmid DNA & \multicolumn{3}{c}{ Number of animals } & \multicolumn{3}{c}{ Urease test IgG titers (mean \pm SD) } \\
\cline { 2 - 3 } \cline { 5 - 7 } immunization & tested & protected & & mean \pm SD & after imm. & after inf. \\
\hline Non imm. & 7 & 0 & $0.46 \pm 0.03$ & $0.06 \pm 0.01$ & $0.22 \pm 0.06$ \\
pUreA & 7 & 0 & $0.41 \pm 0.02$ & $0.29 \pm 0.30^{\circ}$ & $0.81 \pm 0.41^{\circ}$ \\
pUreB & 7 & 0 & $0.26 \pm 0.12^{*}$ & $0.06 \pm 0.02$ & $0.31 \pm 0.08$ \\
pUreA + pUreB & 5 & 0 & $0.28 \pm 0.08^{\circ}$ & $0.19 \pm 0.07^{\circ}$ & $0.48 \pm 0.11^{\circ}$ \\
\hline
\end{tabular}

*Mann Whitney U-test: $p=0.0017$ vs non immunized, $p=0.02$ vs $\mathrm{pUreA} ;{ }^{\circ} \mathrm{Mann}$ Whitney U-test: $p<0.03$ vs non immunized

Summary: DNA immunization with $H p$ urease subunits leads to the appearance of anti-urease seric antibodies but does not prevent bacterial colonization of the host. However, UreB-DNA vaccinated mice present a lower degree of infection as compared to non immunized animals.

Conclusions: DNA immunization might represent a complement to mucosal/oral immunization. Supported by SNF 32-36349.92.

\section{B:23 PROTECTIVE POTENTIAL OF UREASE B POLYPEPTIDES IN THE MURINE MODEL}

C. Doré-Davin, D. Bachmann, P. Michetti, A.L. Blum, I. Corthésy-Theulaz. Division of Gastro-enterology, CHUV, Lausanne, Switzerland

The urease B subunit (569 amino acids, $66 \mathrm{kDa}$ ) of Helicobacter pylori $(\mathrm{Hp})$ protects mice against Helicobacter felis $(\mathrm{Hf})$ infection. In this study, we have examined whether urease B polypeptides were as effective as purified non active urease (apoenzyme) in conferring protection against infection.

Methods: UreB DNA sequences were cloned into an $E$. coli expression vector to produce proteins containing aa $1-569$, aa 220-569, aa 340-569, and aa 220-345, respectively. Specific pathogen-free BALB/c female mice were orally immunized with $H p$ urease/fragments at days $0,7,14$, and 21 in presence of cholera toxin (CT) and challenged at day 28 with $H f$. Presence of $H f$ in gastric biopsies was assessed one month later by rapid urease test (OD at $550 \mathrm{~mm}$ ).

Results:

\begin{tabular}{lrll}
\hline Immunization: & Tested & Protected & $\begin{array}{l}\text { Urease } \\
\text { mean } \pm \text { SD }\end{array}$ \\
\hline Apoenzyme + CT & 10 & $9^{*}$ & $0.02 \pm 0.05$ \\
aa 1-569+CT & 8 & $6^{* *}$ & $0.06 \pm 0.15$ \\
aa 220-569+ CT & 10 & $9^{*}$ & $0.003 \pm 0.008$ \\
aa 340-569+ CT & 10 & 2 & $0.22 \pm 0.17$ \\
aa 220-345 + CT & 7 & 1 & $0.40 \pm 0.17$ \\
CT & 19 & 1 & $0.37 \pm 0.15$ \\
\hline
\end{tabular}

${ }^{*} \mathrm{p}=0.00002,{ }^{* *} \mathrm{p}=0.026$ (Fisher's exact test) compared to CT.

Summary: Deletion of the first 220 amino acids of UreB does not affect the ability of the recombinant protein to confer protection against infection. However, aa 220 to 345 given orally in presence of CT do not protect from infection. Conclusions: Our data suggest that the 120 amino acids located between amino acids 220 and 340 of the B subunit are necessary but not sufficient for protection. Supported by SNF 3236349.92

\section{B:24 ORAL IMMUNIZATION WITH RECOMBINANT UREASE CONFERS LONG-LASTING IMMUNITY}

G. Myers, T. Ermak, K. Georgakopoulos, T. Tibbitts, J. Bakios, H. Gray, J. Pappo, H. Kleanthous, C.K. Lee, T. Monath. OraVax, Inc., Cambridge, Massachusetts, USA

Urease has been shown to confer protection against challenge with $H$. felis in mice. The purpose of the present study was to examine duration of the immune response and long-term protective efficacy of recombinant urease (rUre).

Swiss Webster mice $(n=200)$ were orally immunized four times at weekly intervals with $100 \mu \mathrm{g}$ rUre and $5 \mu \mathrm{g}$ heat-labile enterotoxin of Escherichia coli (LT), or with LT alone. At time intervals of 4, 10, 20, or 40 weeks post immunization, 25 rUre-immunized mice and 25 control mice were challenged with $H$. felis and sacrificed at 2 or 10 weeks post challenge. $H$. felis infection was assessed by quantitative gastric urease assay and by histology. Anti-urease antibody levels were measured in serum and saliva both pre- and post-challenge. Over the 40 week time period, the infection rates in rUre-immunized mice were significantly lower than those in controls $(\mathrm{p}<0.05)$ as assessed by gastric urease activity, with protection levels ranging from $79-100 \%$ at 2 weeks post-challenge and $63-78 \%$ at 10 weeks post-challenge. Anti-urease antibody levels remained elevated in the serum and mucosal compartments at 39 weeks following immunization. This study shows that immunization with rUre and LT results in long-lasting protective immunity against challenge with H. felis.
1B:25 LOCAL IMMUNOGLOBULIN G ANTIBODIES, AND NOT IgA, CONTRIBUTE TO PROTECTIVE IMMUNITY AGAINST GASTRIC H. FELIS INFECTION IN MICE

R.L. Ferrero, J.-M. Thiberge, A. Labigne. Unité de Pathogénie Bactérienne des Muqueuses (INSERM U389), Institut Pasteur, Paris, France

Orogastric immunization of mice with Helicobacter antigens, together with mucosal adjuvants, has been shown to confer immunity in the $H$. felis infection model. The aim of the study was to investigate the humoral responses associated with immunity and to compare these with responses in $\mathrm{H}$. felisinfected mice. To do this, antibody-secreting cells and antibodies present at mucosal and systemic sites in mice were characterized by enzyme-linked immunoassays. It was found that $H$. felis infection in mice preferentially induced the recruitment of plasma cells committed to immunoglobulin A (IgA) synthesis in salivary gland and gastric tissues. Antigen-specific IgA was the major antibody class detected, representing between 9 and $50 \%$ of total IgA in mucosal secretions recovered from these tissues. In contrast, immunization of mice against gastric $H$. felis infection induced the proliferation of large numbers of immunoglobulin $\mathrm{G}$ (IgG)-secreting cells at mucosal tissue sites. Anti- $H$. felis IgG antibodies (accounting for between 3 and $9 \%$ of total IgG), but not specific IgA antibodies, were present in the gastric secretions of immunized animals. Protective immune responses were associated with an augmented synthesis of IgG1 subclass antibodies in the sera. In conclusion, immunization against gastric $H$. felis infection was shown to induce local IgG responses. It is proposed that locally synthesized specific IgG antibodies contribute to immunity against gastric Helicobacter infection.

\section{B:26 IMMUNOBLOT ANALYSIS OF HUMORAL RESPONSE AMONG} HELICOBACTER PYLORI STRAINS ISOLATED FROM DUODENAL ULCER PATIENTS LIVING IN VENEZUELA

M.E. Cavazza ${ }^{1}$, M. Correnti ${ }^{2}$, N. Marcano ${ }^{3}$, G. González Díaz ${ }^{4}$, J. Vivas ${ }^{4}$, M.I. Urrestarazu ${ }^{1}$, N. Serrano ${ }^{1}$, R. Piñero ${ }^{5} .{ }^{1}$ Instituto de Biomedicina, Táchira, Venezuela; ${ }^{2}$ Instituto de Oncología y Hematología, Táchira, Venezuela; ${ }^{3}$ Universidad central de Venezuela, Táchira, Venezuela; ${ }^{5}$ Hospital J.M. Vargas., Caracas, Táchira, Venezuela; ${ }^{4}$ Centro de Control de Cáncer Gastrointestinal Dr. Luis E. Anderson San Cristobal, Edo, Táchira, Venezuela

The purpose of the study was to screen sera of patients with duodenal ulcer (DU) and asymptomatic population using the immunoblot technique to define immunoreactive patterns characteristic of $H$. pylori infection. Methods: Endogastroduodenoscopy was done on 15 patients with dyspeptic symptoms and the biopsy specimens obtained were cultured under microaerofilic conditions. The serological examination came from 15 patients with DU, 11 healthy children under 10 years and 61 teenagers from an endemic gastric cancer state of Venezuela. The soluble antigen material was prepared by sonication of whole cells. Samples containing about $200 \mu \mathrm{g}$ of protein were subjected to SDS-PAGE $10 \%$ acrylamide running gel. The proteins were transfered to nitrocelulose support. Results: The immunoblots of the patients sera infected with $\mathrm{H}$. pylori, showed a characteristic pattern of reactivity to protein bands of: $83,67,63,47$ and $17 \mathrm{kDa}$ for IgG antibodies and $74,67,58 \mathrm{kDa}$ for IgA antibodies. The same reactivity patterns were observed in $3(27.2 \%)$ of sera from healthy children. The reactivity of protein bands was different in the teenager group. The $110-120 \mathrm{kDa}$ band proteins were reactive on the IgG blot of two individuals (7.6\%) but on the IgA blots, these proteins did not show reactivity with any sera tested. The percentage of positive results increased with the band proteins of $83 \mathrm{kDa}$ for IgG and IgA blots $(38.46 \%)$. Only five sera $(19.23 \%)$ were negative in the immunoblot assay. Conclusions. Immunoblot analysis showed that the reactivity patterns were different between sera of asymptomatic population of endemic gastric cancer, healthy children and patients infected with $H$. pylori who live in Metropolitan areas. The presence of immunoreactivity against $H$. pylori antigens would be a good marker for the follow-up of the $H$. pylori infection specially in high risk population living in endemic gastric districts.

\section{B:27 HLA-DQA1 ALLELES AND H. PYLORI INFECTION}

J. Karhukorpi, I. Ikäheimo, S. Silvennoinen-Kassinen, A. Tiilikainen, R. Karttunen. University of Oulu, Oulu, Finland

HLA molecules play an important role in antigen presentation in immune defence against infectious agents. HLA-DQA1*0102 allele was suggested to protect against and $\mathrm{DQA1}{ }^{*} 0301$ allele was suggested to predispose to $\mathrm{H}$. pylori-caused disease in a recently published study involving Japanese patients. To analyze this possible association, we tested DQA1 alleles in infected and non-infected subjects, mostly staff from the medical faculty. 
Methods: H. pylori-specific IgG antibodies were determined by EIA (Pyloriset EIA-G, Orion Diagnostica, Espoo, Finland). HLA-DQA1* typing was done with PCR-SSP. Statistical comparisons were made by Fisher's exact test.

Results: DQA1 allele frequencies were similar in $\mathrm{H}$. pylori antibody positive $(n=50)$ and antibody negative $(n=138)$ individuals. Frequencies of allele 0102 were $15 \%$ vs. $18 \%$ and those of $030124 \%$ vs. $20 \%$ (antibody-positive vs. antibody-negative, $\mathrm{p}=\mathrm{NS}$ ).

HLA-DQA1 homozygosity was, however, increased in the former as compared with the latter $(24 \%$ vs. $12 \%, p=0.03)$.

Conclusions: We could not confirm the possible association between H. pylori infection and certain HLA-DQA1 alleles. Our finding of the increased DQA1 homozygosity in subjects with $\mathrm{H}$. pylori antibodies fits wel with the hypothesis that heterozygosity in MHC genes favors resistance to microbial infections.

\section{B:28 ORALLY-IMMUNIZED IgA DEFICIENT MICE ARE PROTECTED AGAINST H. FELIS INFECTION}

J.G. Nedrud, T. Blanchard, S. Czinn, G.R. Harriman. Case Western Reserve University, Cleveland, OH, USA; Baylor College of Medicine, Houston, TX, USA

Oral immunization with a variety of antigens plus cholera toxin adjuvan can protect mice from $H$. felis infection. Although oral immunization induces mucosal immune responses including IgA in gastric secretions, the mechanism(s) of protection remain ill-defined. To address this issue, IgA deficient mice (produced by gene-targeting) were orally immunized $4 \times$ weekly with $2 \mathrm{mg} H$. felis sonicate plus $10 \mu \mathrm{g}$ cholera toxin. Mice were challenged one week after immunization with $5 \times 10^{6}$ viable $\mathrm{H}$. felis and sacrificed two weeks later. Both wild type immunized mice (1/10 urease positive) and IgA deficient mice (1/10 urease positive) were protected from infection when compared to unimmunized controls (6/8 and 10/11 positive). Both groups of protected mice had comparable levels of $H$. felis-specific serum and gastric IgG. IgA deficient mice did not develop any IgA antibodies but had much higher titers of IgM antibodies that wild type mice (table).

\begin{tabular}{llllll}
\hline Mice & \multicolumn{2}{c}{ Serum Ab $(\log 10)$} & & \multicolumn{2}{c}{ Gastric Ab $(\log 10)$} \\
\cline { 2 - 3 } \cline { 5 - 6 } & IgA & IgM & & IgA & IgM \\
\hline IgA $+/+$ & 3.5 & 4.0 & & 2.5 & 0.9 \\
$\operatorname{IgA}-/-$ & $>1.4$ & 5.5 & & $>0.5$ & 2.5 \\
\hline
\end{tabular}

In conclusion, orally-immunized IgA deficient mice develop high levels of $H$. felis-specific IgM in gastric secretions and are protected from $H$. felis infection.

\section{B:29 ADOPTIVE TRANSFER OF HELICOBACTERSPECIFIC TH1 OR TH2 CELLS EXACERBATES HELICOBACTERASSOCIATED GASTRITIS, BUT ONLY TH2 CELLS REDUCE THE MAGNITUDE OF INFECTION}

M. Mohammadi, S. Czinn, R. Redline, J. Nedrud. Case Western Reserve University, Cleveland, $\mathrm{OH}, \mathrm{USA}$

Previous findings in the $H$. felis-mouse model suggest that TH1 cellular immune responses may contribute to Helicobacter-associated gastritis. To further investigate this issue, a series of adoptive transfer experiments were performed.

Methods: Antigen-specific spleen cells, isolated from immunized/challenged or non-immunized/infected mice, or tissue culture-derived CD4+ T cell lines were adoptively transferred into naive recipients before live bacterial challenge. Recipient mice were sacrificed at various times after challenge and evaluated for gastritis, bacterial load, cellular proliferation, cytokine production, and serum antibody levels.

Results: Transfer of cells from both groups of donors as well as TH1 and TH2 cell lines exacerbated gastric inflammation in the recipients ( $p<$ 0.05). However, when the magnitude of infection was determined for various groups of recipients, only transfer of cells from immunized/challenged (protected) mice and a TH2 cell line (but not cells from infected mice or TH1 cell lines) led to a significant reduction in the bacterial load. The reduction of bacterial load in the recipients of cells from immunized/challenged mice correlated with raised serum IgG1 antibodies in these mice.

Conclusion: These data suggest two different roles for cell-mediated immune responses in Helicobacter infection, one associated with the pathogenesis of disease (TH1 phenotype), and the other associated with protection from or control of infection (TH2 phenotype).

\section{B:30 ANTIBODY RESPONSE TO SPECIFIC H. PYLORI-ANTIGENS IN NONULCER DYSPEPSIA, PEPTIC ULCER AND HEALTH: PREDICTORS OF DISEASE OUTCOME?}

G. Holtmann ${ }^{1}$, H. Mitchell ${ }^{2}$, S. Hazell ${ }^{2}$, N.J. Talley ${ }^{3}$. ${ }^{1}$ Division of Gastroenterology, University of Essen, Germany; ${ }^{2}$ School of Microbiology and Immunology, University of NSW; ${ }^{3}$ Department of Medicine,

University of Sydney, Nepean Hospital

$H$. pylori is linked to the pathogenesis of duodenal ulcers (DU) and may play a role in the development of nonulcer dyspepsia (NUD). However, whether specific $H$. pylori antigens are of clinical importance is unclear. We aimed to investigate whether patterns of antigen recognition differed in infected individuals with DU and NUD. Methods: Studied were $H$. pylor positive patients with DU $(n=50)$, NUD $(n=34)$ and healthy blood donors without dyspeptic symptoms $(n=92)$. Western blot analysis was used to identify immune responses to specific $H$. pylori antigens in serum. The proportion of $H$. pylori infected subjects and total number of antibodies against specific antigens were compared utilizing non-parametric tests. Factor analysis and logistic regression analysis were done to detect specific patterns of $H$. pylori antigens associated with specific disorders. Results: Overall, Western blot analyses yielded significantly more antibody responses in DU and NUD patients as compared to asymptomatic blood donors $(\mathrm{p}<0.01)$. Univariately, antibodies against $120(\mathrm{p}<0.001), 81$ ( $<0.001), 60(\mathrm{p}<0.02)$ and $50 \mathrm{kDa}$ antigens $(\mathrm{p}<0.05)$ were significantly associated with DU. In contrast, the $22 \mathrm{kDa}$ antigen was significantly associated with NUD and there was a negative association between NUD and the $55 \mathrm{kDa}$ antigen $(\mathrm{p}<0.05)$. Factor analysis yielded a two factorial structure with all antigens except the $22 \mathrm{kDa}$ antigen loading on factor one. Conclusions: The pathophysiologic role of $H$. pylori in DU and NUD cannot be attributed to a single antigen expressed by $H$. pylori. While there is no specific pathogenic pattern of antigens, the risk of DU increases with the number of antigens expressed. Lack of the $55 \mathrm{kDa}$ antigen appears to be a risk factor for the development of NUD.

\section{B:31 RESOLUTION OF GASTRITIS AND DURATION OF PROTECTION AGAINST H. FELIS INFECTION AFTER ORAL IMMUNIZATION WITH RECOMBINANT UREASE}

T.H. Ermak, H.K. Kleanthous, G. Myers, R. Ding, C.K. Lee, J. Pappo, T.P. Monath. OraVax, Inc., Cambridge, MA

Several groups including our own have reported an increase in leukocytic infiltration in the gastric corpus of mice immunized with Helicobacter antigens and protected against challenge with $H$. felis. We report here studies on the characteristics of the inflammatory response and its mechanism. Swiss Webster mice were orally immunized with 4 weekly doses of 100 $\mu \mathrm{g}$ recombinant urease (rUre) plus either $10 \mu \mathrm{g}$ cholera toxin (CT) or $5 \mu \mathrm{g}$ heat-labile toxin (LT), or adjuvant alone, and challenged 2 weeks later with $10^{7}$ live $H$. felis. At various intervals postchallenge, gastric tissues were examined for $\boldsymbol{H}$. felis infection, leukocytic infiltration, and epithelial alterations. By gastric urease activity, protection levels after rUre-immunization remained between $70-95 \%$ from 2 weeks through 57 weeks postchallenge. Significantly higher densities of infiltrating leukocytes were found in the corpus of rUre-immunized mice within the first 8 months postchallenge in comparison to LT-controls $(p<0.03)$. Phenotypic analysis of T cells showed that rUre-immunized mice also had greater numbers of $\mathrm{CD}^{+}{ }^{+}$and $\mathrm{CD}^{+} \mathrm{T}$ cells. $\mathrm{CD} 8^{+}$cells were rare in the gastric mucosae of infected LTcontrols and unchallenged control mice. $20 \%$ (21/108) of mice immunized with rUre plus LT but only $5 \%(6 / 116)$ of LT-control mice had epithelial changes consisting of parietal cell loss, hypertrophy of surface epithelium, and microabscesses. When mice were treated with antibiotic triple therapy at 7-9 wk postchallenge, gastritis and epithelial changes in the corpus (12 wk postchallenge) were reduced, suggesting that gastritis was caused by undetected residual bacteria and persistent antigenic stimulation in the mucosa of rUre-immunized mice. These results indicate that oral immunization of mice with rUre produces a long lasting protection against $H$. felis, accompanied by the infiltration of immunoregulatory $\mathrm{T}$ cells, but that sterilizing immunity may not be achieved. Further studies are underway to determine whether these phenomena occur in non-murine hosts.

\section{B:32 UREASE IMMUNIZATION PROTECTS AGAINST REINFECTION BY HELICOBACTER PYLORI IN RHESUS MONKEYS}

C.K. Lee ${ }^{1}$, K. Soike ${ }^{2}$, T. Tibbitts ${ }^{1}$, K. Georgakopoulos ' ${ }^{1}$ J. Bakios ${ }^{1}$, J. Blanchard ${ }^{2}$, J. Hill ${ }^{3}$, J. Pappo ${ }^{1}$, H. Kleanthous ${ }^{1}$, T.P. Monath ${ }^{1}$. ${ }^{1}$ OraVax, Inc., Cambridge, MA; ${ }^{2}$ Tulane Regional Primate Center, Covington, LA $;{ }^{3}$ Clemson University, Columbia SC, USA

Rhesus monkeys (Macaca mulatta) determined to be naturally colonized with $H$. pylori by culture and histology were immunized with either 40 
mg urease administered orally with 25 micrograms LT or sham-immunized with LT alone. A total of 6 doses were administered over an 8 week period. Urease-specific antibodies were generated in the serum in 5 of 6 animals and in the saliva in 3 of 6 animals. The 6 animals receiving LT only and 5 animals receiving urease + LT were treated with a quadruple therapy regimen consisting of $40 \mathrm{mg}$ metronidazole, $24 \mathrm{mg}$ clarithromycin and 44 mg pepto-bismol BID, and $2 \mathrm{mg}$ omeprazole QD for 10 days. $H$. pylori was eradicated in all 11 animals as determined by culture and histology of antral biopsies obtained 5 weeks and 4 months after treatment. The animals were then boosted with either urease + LT or LT alone and challenged with low passage cultures of an $\mathrm{H}$. pylori strain originally isolated from one of the animals in this study. Three inoculations, each consisting of $2 \times 10^{8}$ colony forming units, were delivered to the monkeys by combined oral and intragastric routes every other day. Biopsies taken from the gastric antrum and corpus 3 weeks after inoculation showed a decrease in the level of $H$. pylori colonization in animals receiving urease + LT (a median value of 15 CFUs ranging from 0 to 1,500) compared to animals receiving LT alone (a median value of 1068 CFUs ranging from 57 to 39,000). This difference was statistically significant by the Wilcoxin rank sums test $(p=0.047)$. Later time points will be examined and local (gastric) immune responses will be defined. Studies are also underway to improve vaccine efficacy by combining urease with other antigens, and by the use of alternative routes and adjuvants. This study provides the first evidence for effective immunization of non-human primates against $H$. pylori.

\section{B:33 ORAL IMMUNIZATION OF BALB/C MICE AGAINST HELICOBACTER PYLORI: USE OF HEPARAN SULFATE BINDING PROTEINS COUPLE TO MUCOSAL ADJUVANTS}

E. Ruiz-Bustos, A. Sierra, M.J. Romero, J.L. Ochoa, F. Ascencio. Center for Biological Research, Department of Marine Pathology, La Paz, BCS, 23000 Mexico

Gastrointestinal disorders have long plaqued mankind, and their pathology has changed since they were associated with $H$. pylori was (gastroduodenal ulcers, gastric cancer). Antibiotic therapies do not eradicate the bacteria since there is a high percentage of recurrence in the gastric tissue Therefore, it is important to develop new means to eradicate H. pylori by stimulating the host's own immune system to produce high titers of antibodies against the putative virulence factors of the bacterium. Here, we assess the use of bacterial proteins with Heparan Sulfate-proteoglycan affinity (HSBP) coupled to different mucosal adjuvants, to stimulate a local and systemic immune response of BALB/c mice when orally immunized with these antigens. We observed a significant increase in antibody titers, mainly sIgA and seric IgG, which recognized the HSBP in animals immunized with the antigen covalently coupled to the -subunit of cholera toxin (HSBP-CTB) as revealed by ELISA. Under the same conditions, we also observed high titers of antibody producing cells (SFC) of the IgA isotype among cells in the gastric tissue. Our findings suggest that HSBP-CTB is a putative candidate for stimulating the immune system, thereby preventing the organism from colonizing the gastric mucosa during present and future exposure to this pathogen.

\section{B:34 HELICOBACTER PYLORI CATALASE: A NOVEL ANTIGEN FOR VACCINATION}

T. Kolesnikow ${ }^{1}$, F.J. Radcliff ${ }^{1}$, S.L. Hazell ${ }^{1}$, C. Doidge ${ }^{2}$, A. Lee ${ }^{1}$.

${ }^{1}$ University of New South Wales, Sydney, Australia; ${ }^{2}$ CSL Limited, Melbourne, Australia

Aim: To examine whether immunisation with recombinant catalase can stimulate protection from $H$. pylori challenge.

Methods: A genomic DNA library was constructed from $H$. pylori, strain RU1, in a $\lambda$ ZAP-Express vector. A catalase containing clone was identified by probing the library with a $710 \mathrm{bp}$ fragment of the $H$. pylori catalase gene. The positive clone was excised and the resulting plasmids were introduced into $E$. coli strain XLOLR. A full length catalase clone was identified by placing the clones into $30 \%$ hydrogen peroxide and looking for the formation of bubbles as a measure of catalase activity. The recombinant H. pylori catalase was purified on the basis of size and isoelectric point. Specific Pathogen Free BALB/c mice were immunised on days $0,7,14$ \& 21 with $200 \mu \mathrm{g}$ purified catalase $+10 \mu \mathrm{g}$ of cholera toxin (CT) adjuvant per dose. Control animals were immunised with $1 \mathrm{mg}$ of $H$. pylori sonicate + CT; $1 \mathrm{mg}$ of XLOLR E. coli sonicate + CT; or saline alone. After 3 weeks, the animals were challenged 3 times with the 'Sydney Strain' of $H$. pylori, a mouse colonising strain isolated by our group. Two weeks after challenge the animals were killed and the stomach removed for assessment of infection by urease assay and histology.
Results:

\begin{tabular}{ll}
\hline Group & H. pylori infection (histology) \\
\hline Catalase + CT & $1 / 10$ \\
H. pylori + CT & $2 / 10$ \\
E. coli + CT & $8 / 10$ \\
Saline alone & $10 / 10$ \\
\hline
\end{tabular}

Immunisation with catalase $+\mathrm{CT}$ or $H$. pylori $+\mathrm{CT}$ stimulates a significantly greater level of protection than the control vaccines $\left(\chi^{2}, \mathrm{p}<\right.$ 0.01).

Conclusions: Immunisation with recombinant catalase prevents $H$. pylori colonisation after challenge. Therefore this enzyme should be considered as a potential vaccine candidate.

\section{B:35 ROLE OF HLA-DR AND HLA-DQ ANTIGENS IN THE PATHOGENESIS OF CHRONIC SUPERFICIAL GASTRITIS AND IN THE H. PYLORI INFECTION}

M. Caselli ${ }^{1}$, A. Balboni ${ }^{2}$, E. Guizzardi ${ }^{2}$, P. Gaudenzi ${ }^{1}$, L. Gallerani ${ }^{1}$, V. Alvisi ${ }^{1}$, E. Gandini ${ }^{2} .{ }^{1}$ School of Gastroenterology, University of Ferrara, Italy; ${ }^{2}$ Institute of Medical Genetics, University of Ferrara, Italy

Individuals with different HLA types differ in their susceptibility or resistance to infectious pathogens. In the present study we have analized 61 italian patients with superficial chronic gastritis, $36 \mathrm{H}$. pylori+ and $25 \mathrm{H}$. pylori-, and 126 healthy controls by PCR-SSO typing for DQA1, DQB1, and DR alleles. In contrast with the results in a Japanese population, the distribution of the phenotypic frequencies of DQA1 alleles did not show any significant statistical difference either comparing the two groups with gastritis (H. pylorit and H. pylori-) or comparing the patients $\mathrm{H}$. pylori+ with healthy controls. The distribution of the phenotypic frequencies of the DQB1 alleles showed: a) no difference in the DQB1 allelic distribution between patients $\mathrm{H}$. pylori+ and $\mathrm{H}$. pylori-. b) a statistical significant difference in the frequency of the allele $\mathrm{DQB1} 1^{*} 0501$ between patients $\mathrm{H}$. pylorit and the healthy controls group (36\% vs $15 \%)$ or between patients $\mathrm{H}$. pylori- and the healthy group ( $40 \%$ vs $15.9 \%$ ). When we have considered the whole group of gastritic patients $(n=61)$ compared with the control group $(n=126)$ we obtained a significant difference for the DQB1 ${ }^{*} 0501$ allele $(p=0.00104, p c=0.022, R R=3.2)$. No difference were observed in the DR allelic distribution between patients $\mathrm{H}$. pylori+ and $\mathrm{H}$. pylori-. When we joint the two groups, we observed a significant difference between the phenotypic frequency of the DR1 allele comparing all gastritic patients $(n=61)$ with healthy controls typed for DR $(n=$ 120) $(p=0.0005, p c=0.006, R R=3.6)$. This last statistical significance resulted higher than that observed for the $\mathrm{DQ}-\mathrm{B} 1^{*} 0501$ allele in linkage disequilibrium with DR1, suggesting a possible association of the disease with the DR antigen. 